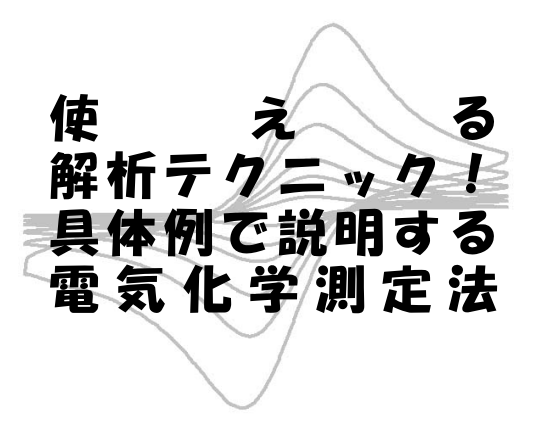

1 はじめに

電気化学インピーダンス法は比較的非破壊で電極およびセ ルの構造・特性を調べることができるため，近年では中心的

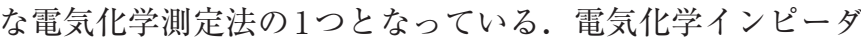
ンス法は線形性を満たす条件において伝達関数を求める方法 であるが，入力信号として正弦波交流信号を電極に与える場 合が多く，交流信号の周波数を変調することで，インピーダ ンスのスペクトル解析が行える。インピーダンススペクトル の測定法は数多くあるが，周波数応答解析装置 (Frequency response analyzer, FRA）の使用により，比較的容易にイン ピーダンススペクトルを測定することができる，幅広い周波 数域で測定したインピーダンススペクトルでは，複数の時定 数分離により，電極構造または電極反応プロセスを詳細に調 べることができる。従って近年では，インピーダンススペク トルの測定そのものよりも，得られたデー夕の解釈と解析に 重点が置かれる。電気化学インピーダンスのデー夕解析には 等価回路を用いることが一般的であり，表面皮膜構造および 多孔質構造などの，電極構造を検討することができる．さら に，電極反応が複数の過程で構成され，電極反応に含まれる 素過程に起因するインピーダンスを考察するのであれば, 「ファラデーインピーダンス」や「拡散のインピーダンス」 を用いた解析法が有効である。

本年 $(2010$ 年), 第 8 回電気化学インピーダンス法国際会 議（2010年6月 5 日 - 11 日，ポルトガル）が開催され，同会 議において電気化学インピーダンス法の最先端が議論された が，そのトピックスを簡単に説明する。電気化学インピーダ ンス法に関して注目された技術的議論は以下である.

・ファラデーインピーダンスと電極素反応の関係.

· CPE (Constant Phase Element) の物理的意味と電気二 重層容量との関係.

・複雑な構造を有する多孔質電極への TLM（Transmission Line Model）の適用，等。

上記に関連して筆者の研究室では, フラクタル構造を有する 多孔質電極への TLM の適用に興味を持ち, 論文発表を行っ ている ${ }^{1)}$ ささらに同会議では，電気化学インピーダンス法の 各分野への適用結果が紹介されたが，主な適用例を以下に示 す.

・各種環境で用いられる金属材料の耐食性評価.

• めっき基板および電析プロセスの評価.

・バイオセンサー等酵素電極の性能評価.

・燃料電池の構造解析と性能評価.

・リチウムイオン二次電池などのエネルギー変換デバイスの 性能評価.
・有機薄膜太陽電池など次世代太陽電池のインピーダンス理 論，等.

電気化学インピーダンス法の応用として筆者の研究室では, 色素増感太陽電池のファラデーインピーダンスを導出し, 電 圧一電流特性との関連を議論している ${ }^{2)}$. 以上の上うに電気 化学インピーダンス法は, 電気化学が関連する現象およびデ バイスの解析手法として大きな注目を集めている。本稿では, 電気化学インピーダンス法による解析に必要な基本原理を簡 単に解説する.

\section{2 電気化学インピーダンス法の位置づけ}

電気化学測定とは，電位または電流を入力または出力信号 として，電極の特性を求める方法である。一般的に，電位は 系の状態と関係し，電流は電極反応速度と関係する。電気化 学測定は定常測定と非定常測定の 2 種で大別できる (Fig. 1).

定常測定とは，電極上での酸化還元反応が平衡，または電 極反応速度が定常を得た状態において電気化学測定を行うも のである。電位測定（ポテンシォメトリー）とは平衡電位ま たは混成電位を測定することで，電極状態を知ることができ る。一方，非定常測定では，電極に何らかの外部信号を与え ることで定常状態からずらし，その緩和過程における応答を 解析することで，素過程や反応中間体に関する情報を得るこ とができる．クロノアンペロメトリーにおける入力信号は電 位ステップ，サイクリックボルタンメトリーにおける入力信 号は繰り返し三角波であり，共に電流応答を測定する。電気 化学インピーダンス法は非定常法の一種であり，入力信号は 微小交流信号である．微小交流信号を用いることで，測定前 後における電極状態の変化が小さいので，電気化学インピー ダンス法は非破壊試験であると考えられる。また交流信号の 周波数を変化させることで, スペクトル解析を行うことがで きる.

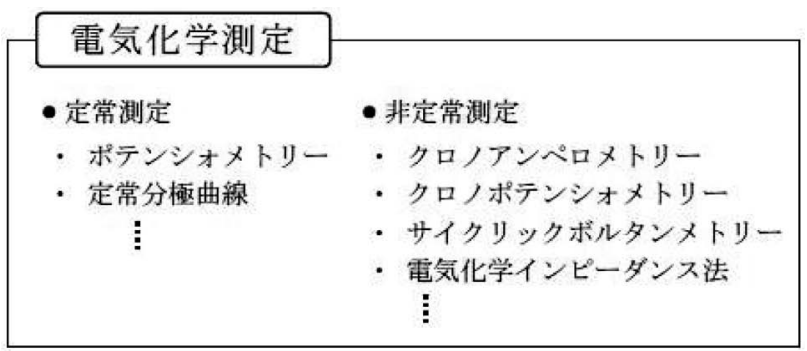

Fig. 1 様々な電気化学測定法 (文献3から引用). 


\section{3 基本的な等価回路}

電荷移動反応を生じない電極の単純な等価回路を Fig. $2(\mathrm{a})$ に示す.このような電極は定常電流が流れないため, 分極性電 極またはブロッキング電極とも呼ばれる. Fig. 2 (a) に示した等 価回路は電気二重層容量 $C_{\mathrm{dl}}$ と溶液抵抗 $R_{\mathrm{sol}}$ で構成されている.

電極／溶液界面において電荷移動が起こる場合の単純な等 価回路を Fig. $2(\mathrm{~b})$ に示す.この等価回路では $C_{\mathrm{dl}}$ と並列に電 荷移動抵抗 $R_{\mathrm{ct}}$ が配置される. 電荷移動反応の速度は電流と比 例関係にあるため, 電荷移動抵抗 $R_{\mathrm{ct}}$ は反応の起こりにくさの 指針となる.すなわち, 電荷移動反応が起こりやすい場合に は $R_{\mathrm{ct}}$ が小さくなり, 起こりづらい場合には $R_{\mathrm{ct}}$ が大きくなる. (a)

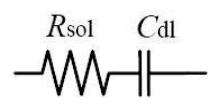

(b)

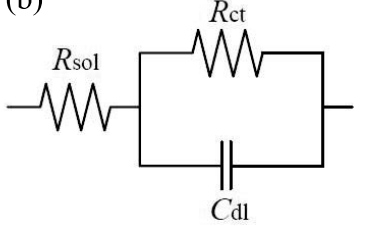

Fig. 22 種の等価回路. $R_{\mathrm{sol}}$ : 溶液抵抗, $C_{\mathrm{dl}}$ : 電気二重層容量, $R_{\mathrm{ct}}$ : 電荷移動抵抗.

\section{4 等価回路とインピーダンススペクトルの関係}

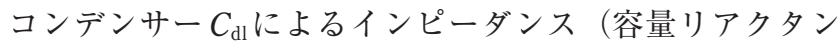
ス $\left.X_{\mathrm{c}}\right)$ は式（1）で示されるように周波数 $f$ の関数となる.

$$
X_{\mathrm{c}}=\frac{1}{\mathrm{j}(2 \pi f) C_{\mathrm{dl}}}
$$

ここで $\mathrm{j}$ は虚数単位である. Fig. 2（a）に示した等価回路は $R_{\mathrm{sol}}$ と $C_{\mathrm{dl}}$ の直列なので，そのインピーダンス $Z$ は実数成分 $Z^{\prime}$ と虚数成分 $Z$ "で構成される複素数で表される.

$$
\begin{gathered}
Z=Z^{\prime}-\mathrm{j} Z^{\prime \prime} \\
Z^{\prime}=R_{\mathrm{sol}} \\
Z^{\prime \prime}=\frac{1}{(2 \pi f) C_{\mathrm{dl}}}
\end{gathered}
$$

ブロッキング電極でのインピーダンススペクトルのナイキス トプロットをFig. 3 （a）に示す.インピーダンススペクト ルは虚数軸に平行な軌跡をとる．実数成分は定数であるが， 虚数成分は周波数に依存し, 周波数が大きくなるとインピー ダンスは $R_{\mathrm{sol}}$ に収束する。一方，インピーダンススペクトル のボードプロットを Fig. 3 （b）に示す.ボードプロットで は, 横軸を周波数の対数 $\log |f|$, 縦軸をインピーダンス絶対

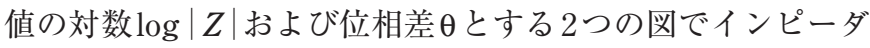
ンススペクトルを示す.高周波数域においては $R_{\mathrm{sol}} \gg \frac{1}{(2 \pi f) C_{\mathrm{dl}}}$ となるので, $\log |Z| \doteqdot \log R_{\text {sol }}$ であり, 位相差 $\theta$ は $0^{\circ}$ である. また, 低周波数域においては $R_{\mathrm{sol}} \ll \frac{1}{(2 \pi f) C_{\mathrm{dl}}}$ となるので, 近 似的に $\log |Z|=-\log f-\log (2 \pi C)$ の関係を持ち, $\log |Z|$ は $\log f に$ 対して-1の傾きを持つ直線となる．さらに，位相
差 $\theta$ はほぼー $90^{\circ}$ となる。

Fig. 2（b）に示した等価回路から導かれるインピーダンス の $Z^{\prime} と Z^{\prime \prime}$ は以下となる。

$$
\begin{gathered}
Z^{\prime}=R_{\mathrm{sol}}+\frac{R_{\mathrm{ct}}}{1+(2 \pi f)^{2} R_{\mathrm{ct}}^{2} C_{\mathrm{dl}}^{2}} \\
Z^{\prime \prime}=\frac{(2 \pi f) R^{2}{ }_{\mathrm{ct}} C_{\mathrm{dl}}}{1+(2 \pi f)^{2} R^{2}{ }_{\mathrm{ct}} C_{\mathrm{dl}}^{2}}
\end{gathered}
$$

さらに, 式 (5) と (6) から $f$ を消去すると以下の関係を得る.

$$
\left(Z^{\prime}-R_{\mathrm{sol}}-\frac{R_{\mathrm{ct}}}{2}\right)^{2}+Z^{\prime \prime 2}=\left(\frac{R_{\mathrm{ct}}}{2}\right)^{2}
$$

Fig. 2（b）に示した等価回路の各素子に適当な値を代入し計 算したインピーダンスをFig. 4に示す. Fig. 4 （a）に示した ナイキストプロットでは, 式（7）で表される半円の軌跡を 描く (容量性半円). 半円の中心は $\left(R_{\mathrm{sol}}+R_{\mathrm{ct}} / 2,0\right)$, 半径は $R_{\mathrm{ct}} / 2$ であり，インピーダンスの軌跡は高周波数および低周 波数極限でそれぞれ実数軸と $R_{\mathrm{sol}}$ と $R_{\mathrm{sol}}+R_{\mathrm{ct}}$ で交わる。 また， 半円の頂点の周波数 $f$ は $R_{\mathrm{ct}} C_{\mathrm{dl}}=1 /(2 \pi f)$ の関係を持ち, $R_{\mathrm{ct}} C_{\mathrm{dl}}$ は時定数と呼ばれる。一方，インピーダンススペクトルのボ (a)

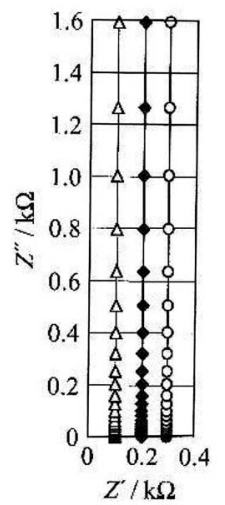

(b)

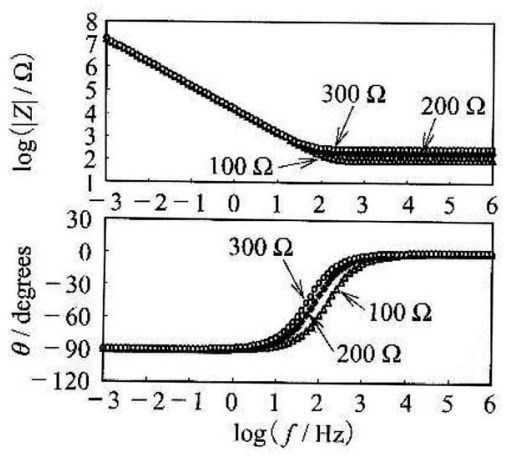

Fig. 3 Fig. 2（a）に示した等価回路から計算されるインピーダ ンススペクトル (文献3から引用) $R_{\mathrm{sol}}: 100 \Omega(\triangle), 200 \Omega$ •), $300 \Omega(\bigcirc), C_{\mathrm{dl}}: 10^{-5} \mathrm{~F}$. (a)

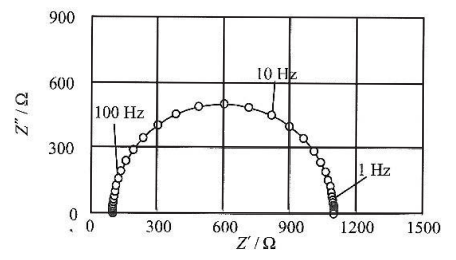

(b)

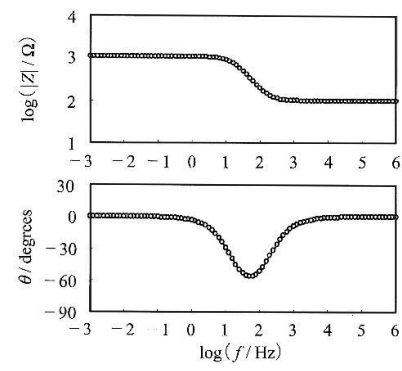

Fig. 4 Fig. 2（b）に示した等価回路から計算されるインピーダ ンススペクトル (文献 3 から引用) $. R_{\mathrm{sol}}: 100 \Omega, C_{\mathrm{dl}}: 10^{-5} \mathrm{~F}$, $R_{\mathrm{ct}}: 1000 \Omega$. 
ードプロットをFig. 4（b）に示す。ナイキストプロットに 対する説明と同様に，高周波数域では $\log |Z|=\log R_{\mathrm{sol}}$ とな

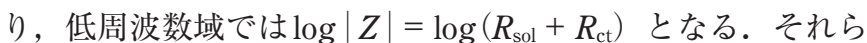
の中間周波数域では, $\log |Z|$ は $\log |f|$ に対して減少し, $\theta$ の 值が負となっている。電気化学インピーダンス法を用い複数 の周波数でインピーダンスを測定することで，等価回路に含 まれる要素を分離することが可能となる.

\section{5 拡散のインピーダンス}

拡散のインピーダンスの有効性を示すために，定常分極曲 線の模式図（Fig. 5）を用いて電極反応素過程を説明する。 可逆でない電極に抒いて電位（i）では電荷移動律速であり， 過電圧に依存して電流值が増加する。さらに過電圧が大きく なり電位（iv）に及ぶと，電極は拡散律速となる。その間の 電位（iii）に抏いては，電荷移動と拡散が電極反応速度を混 合で律速している．定常分極曲線の測定では，得られるデー 夕は電流值なので両プロセスの分離が容易ではない。電気化 学インピーダンス法では，高周波数域での測定において速い プロセスである電荷移動，低周波数域では遅いプロセスであ る拡散に分けたスペクトル解析が行える。

$\mathrm{Ox}+n e^{-} \rightleftarrows \operatorname{Red}$ の酸化還元反応が起こっている平板電極の 拡散に関するワールブルグインピーダンス $Z_{\mathrm{W}}$ は以下のよう に導かれている。

$$
\begin{gathered}
Z_{\mathrm{W}}=\frac{(1-\mathrm{j}) \sigma}{\sqrt{2 \pi f}} \\
\sigma=\frac{R T}{\sqrt{2} n^{2} F^{2} A_{\mathrm{r}}}\left(\frac{1}{D_{0}{ }^{1 / 2} c_{\mathrm{O}}}+\frac{1}{D_{\mathrm{R}}{ }^{1 / 2} c_{\mathrm{R}}}\right)
\end{gathered}
$$

ここで，。は拡散条件に関する定数で， $D_{0}$ と $D_{\mathrm{R}}$ はそれぞれ $\mathrm{Ox}$ と Red の拡散係数 $\left[\mathrm{cm}^{2} \mathrm{~s}^{-1}\right] ， c_{0}$ と $c_{\mathrm{R}}$ はそれぞれ $\mathrm{Ox}$ と Redのバルク濃度〔 $\left.\mathrm{mol} \mathrm{cm} \mathrm{cm}^{-3}\right], A_{\mathrm{r}}$ は電極面積である。生成 物の電極表面から溶液バルクへの拡散を無視し，反応物の溶 液バルクから電極表面への拡散のみを考慮すると式（9）は 以下となる。

$$
\sigma=\frac{R T}{\sqrt{2} n^{2} F^{2} A_{\mathrm{r}}}\left(\frac{1}{D^{1 / 2} c^{*}}\right)
$$

ここで， $D$ と $c^{*}$ はそれぞれ反応物の拡散係数とバルク濃度で ある。

Fig. 6 （a）に示した等価回路から式（8）の $Z_{\mathrm{W}}$ を含む電気 化学インピーダンスは以下となる。

$$
Z=R_{\mathrm{sol}}+\frac{1}{j 2 \pi f C_{\mathrm{dl}}+\frac{1}{R_{\mathrm{ct}}+\frac{(1-\mathrm{j}) \sigma}{(2 \pi f)^{1 / 2}}}}
$$

式 (11) で示されるインピーダンススペクトルの模式図を Fig. 6 (b) に示す. 電気化学インピーダンスのナイキストプロ ットは, 低周波数域で $45^{\circ}$ の傾きを持つ直線の軌跡を示し, 実 数軸に外捙した切片は $R_{\mathrm{sol}}+R_{\mathrm{ct}}-2 \sigma^{2} C_{\mathrm{dl}}$ となる.さらに, 高周 波数域では, 直径が電荷移動抵抗 $R_{\mathrm{ct}}$ である容量性半円となる.

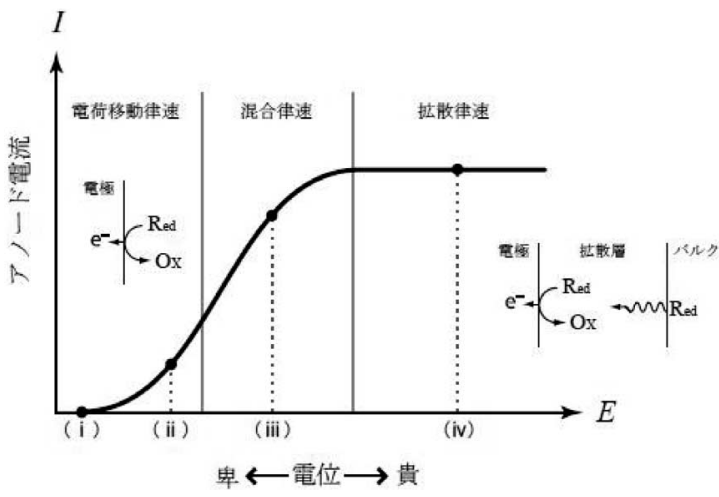

Fig. 5 定常分極曲線の模式図（文献3から引用).

(b)

(a)
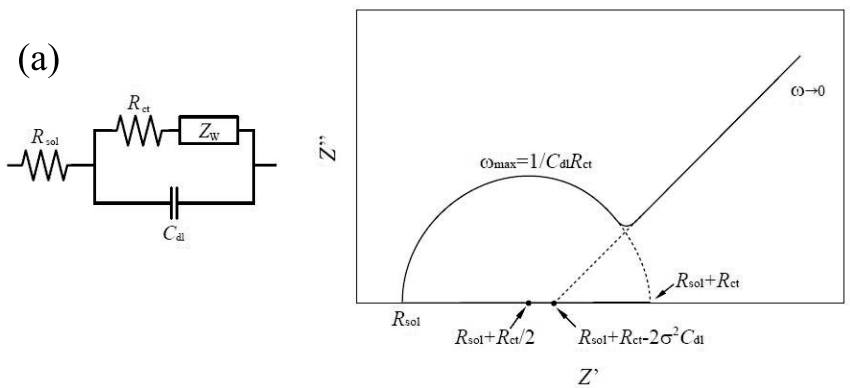

Fig. 6 （a）拡散のワールブルグインピーダンス $Z_{\mathrm{W}}$ を含む等価回 路.（b）（a）に示した等価回路に対応するインピーダンススペク トルの模式図（文献3から引用）。

\section{6 おわりに}

冒頭で述べたように，電気化学インピーダンス法は比較的 非破壊で電極構造と特性を検証できるので，多くの電気化学 分野で使用されている．本稿ではその導入を簡単に解説した が，読者の研究・開発の一助となれば幸いである。引き続き 揭載される応用編により，各適用分野での詳細を理解してい ただけるものと期待する。

\section{文 献}

1) M. Itagaki, Y. Hatada, I. Shitanda, and K. Watanabe, Electrochim. Acta, 55, 6255 (2010).

2) M. Itagaki, K. Hoshino, Y. Nakano, I. Shitanda, and K. Watanabe, J. Power Sources, 195, 6905 (2010).

3）板垣昌幸, 電気化学インピーダンス法 - 原理・測定・解 析一, 丸善 (2008).

キーワード：電気化学インピーダンス, 等価回路, 電荷移動 抵抗，電気二重層容量

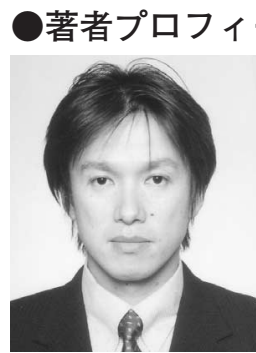

氏 名：板垣 昌幸 Masayuki ITAGAKI

所 属: 東京理科大学理工学部教授

専 門：電気分析化学

趣 味：軽い運動

連絡先：itagaki@rs.noda.tus.ac.jp 